\title{
AGRICULTURAL WATER-SAVING POTENTIAL FOR GUANZHONG IRRIGATION AREAS UNDER DIFFERENT GUARANTEED RATES OF PRECIPITATION
}

\author{
YIN, J. ${ }^{1}-$ FU, Q. ${ }^{1 *}-$ XING, Z. X. ${ }^{1}-$ LU, Y. ${ }^{2}-$ OU, Z. F. ${ }^{1}$ \\ ${ }^{1}$ School of Water Conservancy and Civil Engineering, Northeast Agricultural University \\ No. 59, MuCai Rd., Xiangfang Dist., Harbin 150030, China \\ ${ }^{2}$ Department of Geography and Spatial Information Techniques, Ningbo University \\ No. 818, Fenghua Rd., Jiangbei Dist., Ningbo 315211, China \\ *Corresponding author \\ e-mail: fuqiang@neau.edu.cn; yinjianbnu@163.com
}

(Received $2^{\text {nd }}$ May 2017; accepted $2^{\text {nd }}$ Aug 2017)

\begin{abstract}
The Agricultural Water-saving Potential (AWP) has important influences on water-saving technology development, regional irrigation water management, agricultural production and water ecological balance protection. The study aims to design a reasonable methodology to calculate the AWP and analysis the AWP of Guanzhong irrigation area, in Weihe River Basin of China. The AWP was divided into resource-based AWP and efficiency-based AWP. The former was calculated according to the coefficient of water transmission in canals and irrigation in the field. The latter was estimated on the basis of the field evapotranspiration. The guaranteed rates of precipitation were chosen as the hydrologic conditions. Under the guaranteed rates of $25 \%, 50 \%, 75 \%, 90 \%$ and $95 \%$, the annual total AWPs of the Guanzhong irrigation areas reached $30.69 \times 106 \mathrm{~m}^{3}, 111.67 \times 106 \mathrm{~m}^{3}, 11.75 \times 106 \mathrm{~m}^{3}, 12.52 \times 106 \mathrm{~m}^{3}$, and $14.76 \times 106 \mathrm{~m}^{3}$ respectively. The efficiency-based AWP occupied a proportion of more than $50 \%$ in each condition, which indicated that the improvement of water utilization efficiency should be in preference to improvement of water conveyance efficiency in technology innovation. Summer maize, fruit tree and cotton made the largest contribution to efficiency-based AWP while there was not a big difference among the 3 crops in various irrigated areas when it came to the AWP per unit area, and their average values were 9.4, 6.3 and $4.3 \mathrm{~mm}$ respectively. Then the study comes up with measures and suggestions to improve the AWP according to the planting structures and features of the 9 irrigated areas. This method takes into account the water consumption during the processes of irrigation and crop growth. It can provide the support for water saving agriculture. The accurate calculation of water dissipation coefficient is the key to the efficiency of the AWP method, and the stability of the measurement coefficient will be improved in the future.
\end{abstract}

Keywords: resource-based water-saving, efficiency-based water-saving, Weihe River Basin, precipitation insurance rate, water utilization efficiency

\section{Introduction}

Both water resources per capita and water resources per area are low in China (Yang et al., 2012). Particularly, the distribution of water resources in the country is seriously uneven, with large amount of freshwater resources concentrating in the south. By contrast, the total amount of water resources in the north of the Yangtze River (covering the Haihe River Basin, Huaihe River Basin, Yellow River Basin, and Northwest and Northeast China) is about 546 billion $\mathrm{m}^{3}$, accounting for only $19 \%$ of the national total (Hu et al., 2010). According to the International Water Management Institute (IWMI), water shortage in most countries and regions in the world is correlated to agriculture. The research (Yang et al., 2012) indicates that, if irrigation water used in global food production could be reduced by $10 \%$, people's water demands for all other purposes 
wouldbe met. Accounting for the largest part of the total water use, agricultural water is the most important factor in regional water balance and sustainable utilization of water resources (Belder et al., 2004). Yang and Tian (2009) and Fan et al. (2010) studied the relation between agricultural irrigation water and surface runoff in typical water basins in North China (NC), and the results show that agricultural production may be the major reason for decrease in surface runoff and exhaustion of rivers in most northern river basins. Moreover, groundwater overdraft has resulted in the generation of the world's largest underground cone of depression, sharp drop of underground water level, river blanking, and continuously decreasing water flow in NC; these phenomena indicate that water resources have become increasingly scarce in semi-humid and semi-arid regions and arid regions in China (Moiwo et al., 2009; Zhang et al., 2013; Yin et al., 2016).

Currently, the overall utilization efficiency of irrigation water in China is relatively low, and the biggest water loss is percolation and evapotranspiration in the process of water transmission (Wang et al., 2012a). In addition, farmlands are still the key link of agricultural water saving. The core of agricultural water saving is to reduce and effectively control water use throughout three processes of water transmission and loss in farmlands, which are respectively soil water evaporation, plant transpiration, and soil water percolation (Nair et al., 2013). Because percolating water could be reused through nearby water transfer, the most important factors influencing water consumption on the scale of irrigation area are soil water evaporation and plant transpiration (Yan et al., 2015).

After years of expansion, studies on "agricultural water-saving" have covered all links of agricultural production, and one of the important contents of these studies is to improve the overall utilization efficiency of agricultural water resources (Kifle and Gebretsadikan, 2016). In terms of scale, agricultural water-saving has gone far beyond the concept of "farmland" and was gradually employed 3 scales: plant - farm - area (irrigation area in most cases) (Yang et al., 2012; Nair et al., 2013). The studies are aimed to develop theories and technologies for realizing agricultural water-saving, and strategies on the utilization of water resources. In the next place, except for agricultural water-saving at the technical level, water-saving at the management level is receiving more and more attention as well (Huffaker and Whittlesey, 2003; Hu et al., 2010; Yan et al., 2015; Damerau et al., 2016). In this respect, Agriculture Water-saving Potential, AWP, is an important index for water resources management, which can be used to evaluate the amount of water-saving in a certain area (Horst et al., 2005; Yan et al., 2015). Calculating AWP on the scale of irrigation area has certain practical meaning in both agricultural water-saving and water resource security (Zhang and Guo, 2016).

The concept of "Water-saving Potential" was first proposed in researches on urban and residential water management. Dixon et al. (1999) evaluated cities' water-saving potentials in studying the effect of reclaimed water reuse and rainwater utilization on cities' water-saving capacity. Based on investigations, Yurdusev and Kumanlıoğlu (2008) divided domestic water into different categories of water used respectively in washroom, toilet, bathroom, kitchen, washing machine, dishwasher, and for watering flowers outside, washing cars, etc., and defined water-saving potential as the sum of water-saving amounts achieved under all the categories. By using the concept of agricultural water-saving for reference, researches on estimation of AWP play a more and more important role in water resources management. Karimov et al. (2012) calculated the water-saving potential of Fergana Valley using the "water accounting procedures", which are based on the principle of water balance. According to the 
method, they first analyzed the using condition of the water resources in the study area, then worked out the amount of ineffective water consumption, namely the water-saving potential, and finally proposed some measures to reduce the ineffective water consumption, such as evapotranspiration reduction and depression detention, and to increase effective utilization, such as expansion of planting area. With the geoinformation system (GIS) and remote sensing (RS) technologies being widely used in the calculation of water resources potential, AWP on a regional scale has been gradually introduced to various studies. Horst et al. (2005) analyzed the water saving potential through the application efficiency, the distribution uniformity and total applied irrigation depths with furrow irrigation in Fergana, Aral Sea basin, to assess the potential for improving the performance of furrow irrigation in the central part of the Fergana Valley, Uzbekistan. Yan et al. (2015) project the results of such experiments for winter wheat, maize, and cotton to basin scale to assess their potential in restoring sustainable water consumption. The study employed the remote sensing modelETWatch (Wu et al., 2012) for calculating the crop water comsuption in planting area, and found that the mulching, which would reduce the over-consumption by $25 \%$, is the most promising option for farmers in Hai River Basin.

China has great AWP (Yang et al., 2009; Damerau et al., 2016), and the utilization efficiency of agricultural water resources in China will be finally improved by relying on reasonable irrigation methods, adopting advanced irrigation technologies, establishing perfect irrigation managing system and institution, and improving biological attributes of fields and crops, so as to effectively alleviate the pressure from water resource shortage (Yan et al., 2015). The Guanzhong region in Weihe River Basin serve as the bond and bridge connecting the western and eastern regions in North China. The Guangzhong region includes nine main irrigation areas, which are the major grainproducing areas in this region. In recent years, the economic and social development in this region has been limited by the serious situation of water shortage. Although the local government devotes itself to adjusting water utilization structure, agriculture is always the largest source of water use (Tang et al., 2016). The total amount of water resources in the Weihe River Basin is 10.683 billion $\mathrm{m}^{3}$, with total surface water resources being 9.012 billion $\mathrm{m}^{3}$. By 2015 , the overall utilization ratio of surface water resources in the river basin reached to near $30 \%$, but the potential was low, with no potential left in some tributaries; the total amount of groundwater resources is 4.506 billion $\mathrm{m}^{3}$, but the exploitation rate has exceeded $62 \%$, indicating this region is a seriously overdraft area (Ministry of Water resources of the P. R. China 2015). The water deficit is expected to be more than 2.4 billion $\mathrm{m}^{3}$ by 2020 , and more than 3.0 billion $\mathrm{m}^{3}$ by 2030 (Tang et al., 2016). Meanwhile, the productivity of agricultural water resources in the irrigation areas is low, being $1 \mathrm{~kg} \cdot \mathrm{m}^{-3}$ on average, much lower than that other agriculturally advanced countries (Tang et al., 2014a). The causes for the low water resource efficiency mainly include lack of water-saving hi-tech applications, low lining rate of water conveyance canals, and insufficient researches on the irrigation areas' actual carrying capacity of water resources (Tang et al., 2014b). So, there is a great potential in exploiting water resources in this region, but the question is: how much is the potential after applying agronomic measures and water-saving irrigation technologies? Reasonable analysis of AWP has great practical and referential significance in developing agricultural water-saving and making water-saving policies and water resources utilizing plans. 
Considering that water dissipation mainly occurs in two different processes: water transmission (Tang et al., 2014a) and field evapotranspiration (Wu et al., 2012; Pereira, 2017), water consumption could be influenced directly by changing the two links (Wang et al., 2011). The two processes were discussed separately in this study. The amount of water that can be saved in the process of water transmission is denoted as resource-based saving amount, and the amount of water that can be saved in the field is denoted as efficiency-based saving amount (Wang et al., 2011). In addition, at different precipitation levels, the amounts of irrigation water are different from each other (Bennett et al., 2014; Siderius et al., 2015), so precipitation has to be considered in discussions on water-saving potential and the potential shall be estimated at different Guaranteed Rate of Precipitation (GRP) (Zhang et al., 2007).

By selecting the climate condition (precipitation), in which the GRP was respectively $25 \%, 50 \%, 75 \%$, and $90 \%$, the water-saving potentials of the main irrigation areas in the Guanzhong region were analyzed. The water-saving potentials of main crops (winter wheat, summer corn, cotton, fruit tree, cole) in the irrigation areas under the extreme drought condition, in which the GRP was 95\%, were analyzed emphatically. Finally, some suggestions on agricultural water-saving modes were proposed according to the current water-saving technologies and the features of planting structure in the nine irrigation areas. This study aims to establish a method to estimate water saving potential, as a theoretical basis for effective utilization of water resources in the irrigation areas and comprehensive development and utilization of water resources in the Weihe River Basin.

\section{Materials and Methods}

\section{The Study Area}

Guanzhong irrigation areas are located in Shaanxi Province, and involve 5 prefecture-level cities: Baoji, Xi'an, Xianyang, Tongchuan, and Weinan. Agricultural irrigation water in Shaanxi Province concentrates in the areas. Including 9 major irrigation areas and covering a total area of $22,000 \mathrm{~km}^{2}$, Guanzhong irrigation areas are mainly distributed in the Weihe Valley and valleys of its tributaries (Fig. 1). The irrigation areas are located in the continental monsoon climate zone. with a multi-year average precipitation of $600 \mathrm{~mm}$. The mean annual temperature varies from $7.2{ }^{\circ} \mathrm{C}$ to $15.2^{\circ} \mathrm{C}(\mathrm{Wu}$ and Sun, 2016). Precipitation concentrates in July and August, and the precipitation in the two months accounts for nearly $50 \%$ of the annual total (Wu et al., 2017). The irrigation areas enjoy abundant sunshine, with a multi-year average sunshine duration of 1,900-2,400 h. Annual actural evapotranspiration in the irrigation areas is 900-1200 $\mathrm{mm}$ (Wu et al., 2017). The difference between annual evapotranspiration and precipitation is relatively great, with the highest in summer and lowest in winter and the difference in spring is higher than that in autumn. Defined as semi-arid and semi-humid irrigated agricultural areas in warm temperature zone, Guanzhong irrigation areas are suitable for planting a variety of crops. Guanzhong irrigation areas account for $1 / 3$ of the total grain production in Shaanxi Province (Wang et al., 2011). In addition, vegetables, fruits, and other commercial crops are widely grown in the areas as well, and multiple-cropping index is high. The main food crops in the irrigation areas include wheat, maize, and beans, and the commercial crops include cotton, oil plants, fruits, vegetables, etc. Fruit-planting areas 
are mainly located in Baojixia, Luohuiqu, Yangmaowan, Shibaochuan, Taoqupo irrigation areas (Wang et al., 2012b; Yin et al., 2013).

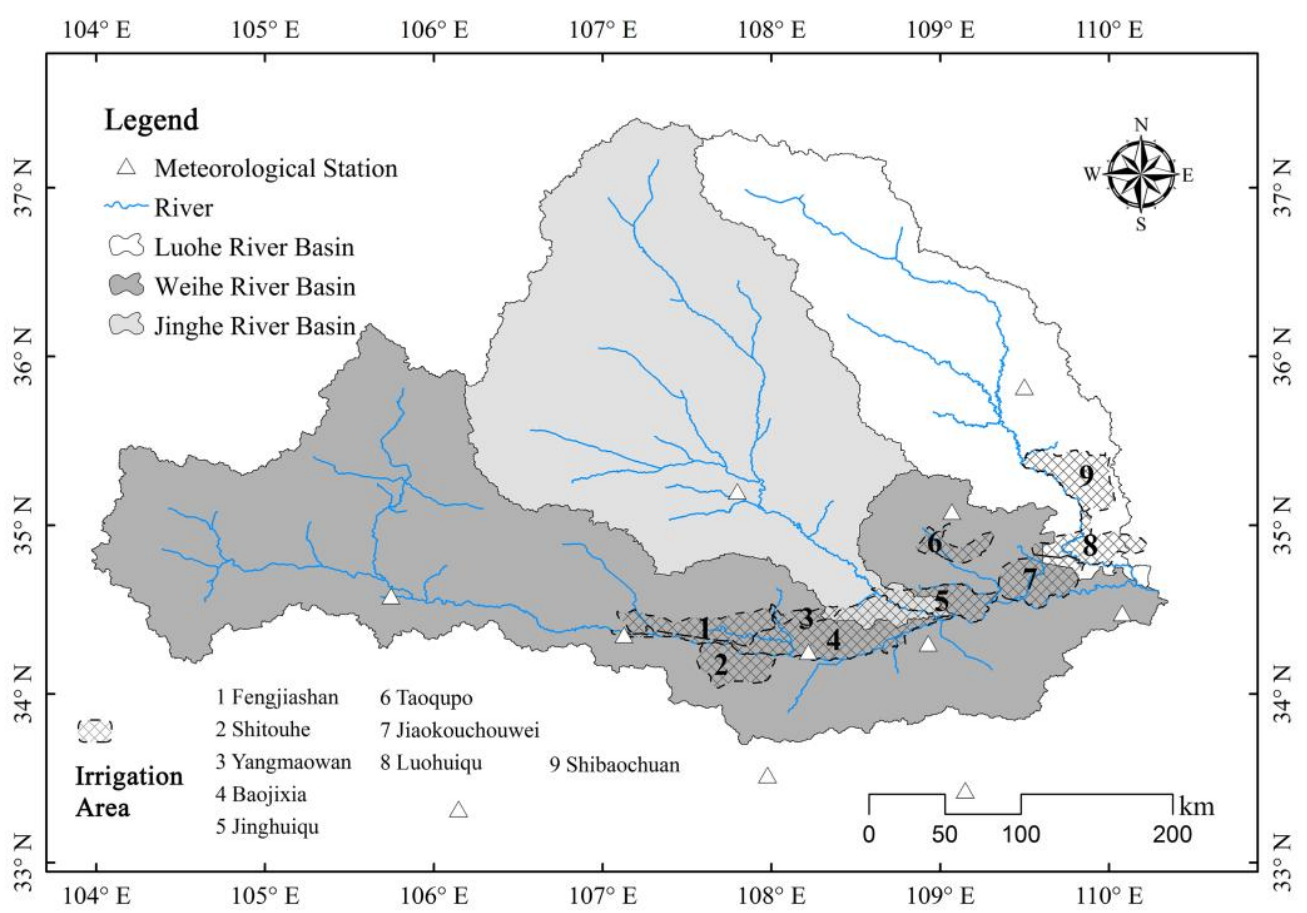

Figure 1. Map of the 9 irrigation areas in Guanzhong area

Over the years, the average annual amount of diverted water in the irrigation areas is 1.787 billion $\mathrm{m}^{3}, 82.65 \%$ of which is diverted by means of ground channel system; the other water is drawn from on-site wells (Yin et al., 2013). The irrigation water for the irrigation areas is mainly taken from Jinghe River, Luohe River, and Weihe River, but the runoff of these rivers is distributed unevenly throughout the year, with the runoff from June to October accounting for 50-70\% of the annual runoff (Wang et al., 2011).

\section{Data sources}

Meteorological and hydrological data used in this study includes precipitation, temperature, relative humidity, wind speed, sunshine duration, air pressure, vapor pressure, and evapotranspiration data recorded by a number of meteorological stations in the Guanzhong region over 35 years (1981-2015) and provided by China Meteorological Data Sharing Service System (http://data.cma.cn/) (the distribution of the meteorological stations is shown in Fig. 1). Other data includes social and economic data (mainly about agricultural water and crop structure, such as the area of main crops in Guanzhong irrigation areas, and irrigation water use), which was collected from statistical yearbooks of Shaanxi Province and official reports on water resources of the Weihe River Basin. After collecting natural and social original data, spatial interpolation method was then used to obtain the mean value of Guanzhong irrigation areas. 


\section{Methodology}

\section{Theoretical AWP}

In the study, we divided AWP into two types, namely resource-based water-saving potential and efficiency-based water-saving potential. The resource-based water-saving potential refers to the saving amount that is achieved by reforming or adjusting water supply to reduce water evapotranspiration and deep percolation; the efficiency-based water-saving potential refers to the saving amount that is achieved by controlling the soil water required for crop growth. The total water-saving potential is the sum of resource-based water-saving potential, $W_{r}$, and efficiency-based water-saving potential, $W_{e}$, as shown in (Eq.1):

$$
W=W_{r}+W_{e}
$$

where, $W$ represents the water-saving potential of an irrigation area, and the subscripts indicate the types of water-saving potential.

The equation for calculating the maximum water-saving potential of a region, $W_{r, m}$ is written as:

$$
W_{r, m}=D_{c}+D_{f}=\left(1-\xi_{c}\right) I_{g}+\xi_{f}\left(1-\xi_{c}\right) I_{g}=\left(1+\xi_{f}\right)\left(1-\xi_{c}\right) I_{g}
$$

where, $D$ respectively represent water loss in the process of water transmission by channels $\left(D_{c}\right)$ and deep percolation in the field $\left(D_{f}\right)$, which can be calculated by using the gross irrigation water amount $I_{g}$, the coefficient of water transmission by channels $\xi_{c}$, and the coefficient of irrigation in the field $\xi_{f}$, From being drawn from water sources to being assimilated by crops, irrigation water is first converted to soil water after being transported to farmlands through channels, and then used by crops through transpiration to generate biomass. Meanwhile, some of irrigation water would lose in forms of soil evaporation, deep percolation, and surface runoff. Therefore, the actual amount of irrigation water needed by crops is much higher than the net irrigation water demand.

The resource-based water-saving coefficient $\xi_{r}$ is the ratio of resource-based watersaving amount to the gross irrigation water amount, written as:

$$
\xi_{r}=W_{r, m} / I_{g}=\left(1+\xi_{r}\right)\left(1-\xi_{r}\right)
$$

The resource-based water utilization coefficient, $\zeta_{r}$, is written as:

$$
\zeta_{r}=1-\xi_{r}=1-\left(1+\xi_{r}\right)\left(1-\xi_{r}\right)
$$

If the coefficient of water transmission by channels and the coefficient of irrigation in the field are known, the resource-based water utilization coefficient could be calculated.

Efficiency-based water saving includes two aspects: reducing ineffective water consumption in the growing process of crops, and reducing water consumption by adjusting crops' water consumption process based on crops' physiological characteristics. Thus, efficiency-based water-saving potential includes the potential from reduction of ineffective water consumption and the potential from reduction of 
crop evapotranspiration. The equation for calculating efficiency-based water-saving amount is written as:

$$
W_{e, m}=E T_{\text {ine }}+\varphi_{1}\left(E T-E T_{\text {ine }}\right)=\varphi_{2} E T+\varphi_{1}\left(E T-\varphi_{2} E T\right)=E T\left(\varphi_{1}+\varphi_{2}-\varphi_{1} \varphi_{2}\right)
$$

where, $E_{\text {ine }}$ represents the ineffective water consumption in the field, which is mainly the reduced evaporation from soil and can be expressed as a percentage of crop water consumption (evapotranspiration, ET); $\varphi_{1}$ represents the percentage of water consumption reduction in farmlands achieved by adjusting crops' physiological process; $\varphi_{2}$ represents the percentage of water consumption reduction in farmlands achieved by adopting covering technologies and other agronomic measures.

The efficiency-based water-saving coefficient $\xi_{e}$ is the ratio of the water-saving amount to evapotranspiration, written as:

$$
\xi_{e}=W_{e, m} / E T=\left(\varphi_{1}+\varphi_{2}-\varphi_{1} \varphi_{2}\right)
$$

The efficiency-based water utilization coefficient $\zeta_{e}$ is written as:

$$
\zeta_{e}=1-\xi_{e}=1-\left(\varphi_{1}+\varphi_{2}-\varphi_{1} \varphi_{2}\right)
$$

If the evapotranspiration percentage under the condition of less land coverage and the percentage of reduction achieved by sacrificing some yield are known, the efficiency-based water utilization coefficient could be calculated.

\section{Actual AWP}

The following assumptions are made in the analysis of maximum water-saving potential of the irrigation areas. For resource-based water-saving potential, assume the maximum utilization coefficient of irrigation water is 1 (the utilization coefficient of channel water is 1 , and the utilization coefficient of field water is 1). For efficiencybased water-saving potential, assume the current water consumption of crops is the maximum water consumption. In practice, the utilization coefficient of irrigation water is generally less than 1 . With respect to efficiency-based water saving, though crop water consumption could be reduced by using covering technologies and other measures and optimal irrigation water amount and other variables could be determined by water generation function and efficiency curve, the irrigation water for the irrigation areas is relatively less in actual production and can hardly meet crops' water demand, thus making the evapotranspiration in actual water consumption less than the maximum one.

The equation for calculating actual potential water saving amount $W_{p}$ of the irrigation areas is written as:

$$
W_{p}=I_{d} / \zeta_{2}-I_{d} / \zeta_{1}
$$

where, $\zeta_{1}$ and $\zeta_{2}$ respectively represent the resource-based water utilization coefficients before and after applying water-saving technologies, equal to the product of the utilization coefficient of channel water, $\xi_{c}$, and the utilization coefficient of field water, $\xi_{f}, I_{d}$ represents the net irrigation water demand of crops in the irrigation areas, which 
depends on crops' evapotranspiration $(E)$, precipitation $(P)$, effective utilization coefficient of precipitation $\alpha$, and crop planting area $A$ :

$$
I_{d}=\sum_{i=1}^{n} A_{i}\left(E_{i}-P \alpha-G\right)
$$

where, the subscript, $i$, represents crop variety; $A_{i}$ and $E_{i}$ respectively represent the planting area and evapotranspiration of the $i$ th crop; $P$ and $\alpha$ are respectively the precipitation and the effective utilization coefficient of precipitation in the region. Because the groundwater level in the Guanzhong region is relatively deep, the influence of groundwater contribution $G$ on the crops could be neglected and the value could be approximated as 0 .

The equation for calculating the resource-based water utilization coefficient, namely the utilization coefficient of irrigation water, is written as:

$$
\zeta_{1}=\xi_{c, 1} \times \xi_{f, 1}, \zeta_{2}=\xi_{c, 2} \times \xi_{f, 2}
$$

The utilization coefficient of channel water could be increased by canal lining and other measures, and the utilization coefficient of field water could be increased by land leveling, ridged field improvement, and applications of water-saving irrigation technologies. If the irrigation area of the irrigation areas and irrigation water $(I)$ stay unchanged, and the utilization coefficient of field water is improved to $\xi_{f, 2}$, then the resource-based water-saving amount is:

$$
W_{r, p}=I\left(\zeta_{2}-\zeta_{1}\right)=I \times \xi_{r, p}
$$

where $\xi_{r, p}$ represents the resource-based water-saving coefficient, which can be written as:

$$
\xi_{r, p}=\xi_{c} \times \xi_{f, 2}-\xi_{c} \times \xi_{f, 1}
$$

Efficiency-based water saving mainly includes two aspects: reducing ineffective water consumption in the growing process of crops, and reducing water consumption by adjusting crops' water consumption process based on crops' physiological characteristics. The equation for calculating the efficiency-based water-saving potential, $W_{e, p}$, is written as:

$$
W_{e, p}=\Delta E T / \zeta_{2}=E T_{b}\left(\varphi_{1}+\varphi_{2}-\varphi_{1} \varphi_{2}\right) / \zeta_{2}
$$

where, $\Delta E T$ is the reduction in crop evapotranspiration; $E T_{b}$ is the water consumption of crops in the base year, which can be obtained by using the Penman-Monteith equation, recommended by FAO56 and various crop coefficients (Pereira et al., 2015). 


\section{Results}

\section{AWP with different GRP}

Resource-based water-saving amount is reduced water percolation and evaporation, which are saved by implementing water-saving projects. After implementing watersaving projects in Guanzhong irrigation areas, the utilization coefficient of channel water and the utilization coefficient of irrigation water were increased to 0.65 and 0.50 respectively. According to on-site investigations, the water utilization efficiency in Guanzhong irrigation areas has been improved to 0.55 . Thus, if taking $\xi_{c}$ as 0.65 , then $\xi_{f}$ would reach to 0.85 (Wang et al., 2012b). According to the technical specification for water-saving irrigation engineering (GB/T 50363-2006) (Ministry of Housing and Urban-Rural Development of the P. R. China, 2006), the irrigation water utilization coefficient and the canal conveyance coefficient in large irrigation areas shall be no less than 0.50 and 0.55 , and the utilization coefficient of field water in irrigation areas for growing rain-fed crops shall be no less than 0.90 (Table 1). Through comparison with the specifications, we can learn that, after implementing water-saving projects in Guanzhong irrigation areas, the utilization coefficient of irrigation water and the canal conveyance coefficient have met the requirements of the specifications, but the utilization coefficient of field water is still at a low level. Therefore, the resource-based water-saving potential is mainly from improving the utilization coefficient of field water, which can be improved by applying land leveling technology, ridged field improving technology, surge flow irrigation technology, and conduit conveyance-based sprinkling and micro-irrigation technologies.

Table 1. Water utilization coefficient in the specification

\begin{tabular}{|c|c|c|c|}
\hline $\begin{array}{l}\text { Technical specification for irrigation } \\
\text { projects with low pressure pipe } \\
\text { conveyance (GB/T 20203-2006) } \\
\text { (Standardization Administration of } \\
\text { the P. R. China 2006) }\end{array}$ & $\begin{array}{c}\text { The utilization } \\
\text { coefficient of } \\
\text { canal water } \geq \\
0.95\end{array}$ & $\begin{array}{c}\text { The utilization } \\
\text { coefficient of } \\
\text { field water } \geq \\
0.85\end{array}$ & $\begin{array}{l}\text { The utilization } \\
\text { coefficient of } \\
\text { irrigation water } \\
\quad \geq 0.80\end{array}$ \\
\hline $\begin{array}{l}\text { Technical specification for water-saving } \\
\text { irrigation engineering (GB/T 50363- } \\
\text { 2006) (Ministry of Housing and Urban- } \\
\text { Rural Development of the P. R. China } \\
\text { 2006) }\end{array}$ & $\begin{array}{l}\text { Large-scale } \\
\text { irrigation } \geq 0.55 \\
\text { Medium-sized } \\
\text { irrigation } \geq 0.65 \\
\text { Small-scale } \\
\text { irrigation } \geq 0.75 \\
\text { Canal seepage } \\
\text { control } \geq 0.90 \\
\text { Pipeline convey } \\
\text { water } \geq 0.95\end{array}$ & $\begin{array}{l}\text { Rice based } \\
\text { irrigation } \geq 0.95 \\
\text { Dry crops based } \\
\text { irrigation } \geq 0.90\end{array}$ & $\begin{array}{c}\text { Large-scale } \\
\text { irrigation } \geq 0.50 \\
\text { Medium-sized } \\
\text { irrigation } \geq 0.60 \\
\text { Small-scale } \\
\text { irrigation } \geq 0.70 \\
\text { Well irrigation } \geq \\
0.80 \\
\text { Drip irrigation } \geq \\
0.90\end{array}$ \\
\hline
\end{tabular}

Meanwhile, some of Guanzhong irrigation areas are well-canal combined irrigation areas, in which the regional conduit conveyance coefficient (the percentage of conduit conveyance $\geq 0.95$ ) could be greatly increased through implementing conduit conveyance, thus improving the utilization coefficient of irrigation water in the irrigation areas. If the conduit conveyance coefficient of the conduit-based irrigation areas (such as sprinkling irrigation areas, micro-irrigation areas, and trickle-irrigation areas) is 0.95 and the utilization coefficient of field water is 0.90 , then the utilization 
coefficient of irrigation water in the irrigation areas could reach up to 0.855 , greatly improving the utilization efficiency of irrigation water. If total water demand stays unchanged, saving of irrigation water could be achieved by increasing conduit conveyance coefficient. Possible resource-based water-saving amount in different situations could be calculated according to crop planting structure and water consumption structure in different Guanzhong irrigation areas.

\section{Resource-based AWP of typical irrigation area}

In order to determine the precipitation at the GRP of $25 \%, 50 \%, 75 \%$, and $90 \%$ respectively, we carried out a precipitation frequency analysis by using the irrigation areas' meteorological data from 1955 to 2015 through Pearson type III curve (Bobée, 1975; Feng et al., 2014), and further calculated the AWPs of the irrigation areas in the corresponding years. Table 2 shows the resource-based AWP of the Baojixia irrigation area.

Table 2. The resource-based AWP of Baojixia Irrigation Area in different hydrological years

\begin{tabular}{|c|c|c|c|c|}
\hline \multirow{2}{*}{$\begin{array}{l}\text { Hydrological } \\
\text { year (GRP) }\end{array}$} & \multirow{2}{*}{$\begin{array}{c}\text { Water } \\
\text { withdrawal } \\
\left(\mathbf{1 0}^{4} \mathbf{m}^{3}\right)\end{array}$} & \multicolumn{2}{|c|}{$\begin{array}{l}\text { Utilization coefficient of irrigation } \\
\text { water }\end{array}$} & \multirow{2}{*}{$\begin{array}{l}\text { Water-saving amount } \\
\qquad\left(10^{4} \mathrm{~m}^{3}\right)\end{array}$} \\
\hline & & $\begin{array}{c}\text { Current } \\
\text { situations }\end{array}$ & $\begin{array}{c}\text { Using water-saving } \\
\text { technologies }\end{array}$ & \\
\hline $25 \%$ & 14893 & 0.55 & 0.585 & 891 \\
\hline $50 \%$ & 33609 & 0.55 & 0.585 & 2011 \\
\hline $75 \%$ & 33609 & 0.55 & 0.585 & 2011 \\
\hline $90 \%$ & 48897 & 0.55 & 0.585 & 2925 \\
\hline
\end{tabular}

*Through the actual investigation, we have learned that under the current conditions of irrigation water use coefficient is 0.55 , higher than the target value 0.50 of the transformation of Guanzhong Irrigation Area. After using of water-saving technology, the water use coefficient is raised to 0.585 , in which channel water use efficiency is 0.65 with reference to the condition of Guanzhong Irrigation Area reconstruction. According to TSWI (GB/T 503632006), the field-water use coefficient is 0.90 .

\section{Efficiency-based AWP of typical irrigation area}

A covering layer can significantly reduce crops' water consumption. In Guanzhong irrigation areas, covering materials are lacking in the planting season of winter wheat, and covering technologies are seldom used at that time. Therefore, in the growing period of winter wheat, $\varphi_{2}=0$. Large combines are generally used to harvest wheat in Guanzhong irrigation areas. When harvesting, the combines would only take wheat grains away, leaving straw on the soil surface. In addition, wheat-maize continuous cropping system is generally employed in Guanzhong irrigation areas, so summer maize is often covered by wheat straw and stubble during its growing period. According to the studies(Chen et al., 2004; Li et al., 2012), thanks to the covering layer formed by wheat stubble, the evapotranspiration of summer maize would decrease by $10-20 \%$ to about $30-50 \mathrm{~mm}$. In addition, straw mulching can increase the water utilization efficiency of fruit trees by $20-30 \%$ (Liu et al., 2013) in general, and according to the equation for calculating water utilization efficiency, the water consumption of the trees would decrease by $15-25 \%$ with little change in yield. If fruit trees' annual water consumption is $600 \mathrm{~mm}$, then their water consumption would decrease by $90-150 \mathrm{~mm}$ after applying covering technologies. In Guanzhong irrigation areas, single cropping system is generally used for planting cotton. Due to soil preparation and other factors, there is 
little possibility that the stubble of the previous crop is used as the covering layer. Therefore, it is more likely to implement plastic film mulching. As indicated by literature, plastic film mulching can decrease the water consumption of cotton by 13$18 \%$ in general (15\% on average) (Zuo et al., 2010; Liu et al., 2013). The growing period of rape in the Guanzhong Plain is generally from September to May of the next year, and covering technologies are seldom used in this period. When calculating efficiency-based water-saving potentials, conditions of using the water-saving measure of covering to improve crops' water utilization efficiency were mainly considered in this study, with the measure of changing crops' physiological structure being put aside. The percentages $\left(\varphi_{2}\right.$, namely) of reduced water consumption of different crops in the Guanzhong region, which is achieved by using covering technologies, are shown in Table 3.

Table 3. The Efficiency-based AWP under mulching condition of Baojixia Irrigation Area

\begin{tabular}{|c|c|c|c|c|c|c|}
\hline \multirow{3}{*}{$\begin{array}{l}\text { Hydrological } \\
\text { year (GRP) }\end{array}$} & Crop & $\begin{array}{l}\text { Winter } \\
\text { wheat }\end{array}$ & $\begin{array}{c}\text { Summer } \\
\text { corn }\end{array}$ & Cotton & $\begin{array}{c}\text { Fruit } \\
\text { tree }\end{array}$ & Cole \\
\hline & $\varphi 2$ & 0 & $15 \%$ & $15 \%$ & $20 \%$ & $0 \%$ \\
\hline & $\begin{array}{c}\text { Area of mulching } \\
(50 \% \text { of the acreage })\left(\mathrm{hm}^{2}\right)\end{array}$ & $\mathbf{5 1 7 8 0}$ & 45353 & 180 & 27200 & 4467 \\
\hline \multirow{5}{*}{$25 \%$} & Evapotranspiration (mm) & 407 & 374 & 554 & 634 & 345 \\
\hline & Precipitation $(\mathrm{mm})$ & 161 & 540 & 654 & 654 & 343 \\
\hline & $\begin{array}{l}\text { Evapotranspiration under } \\
\text { mulching condition }(\mathrm{mm})\end{array}$ & 407 & 318 & 471 & 507 & 345 \\
\hline & Theoretical AWP $\left(10^{4} \mathrm{~m}^{3}\right)$ & 0 & 1697 & 10 & 2300 & 0 \\
\hline & Actual AWP $\left(10^{4} \mathrm{~m}^{3}\right)$ & 0 & 0 & 0 & 0 & 0 \\
\hline \multirow{5}{*}{$50 \%$} & Evapotranspiration (mm) & 407 & 364 & 554 & 591 & 345 \\
\hline & Precipitation (mm) & 162 & 340 & 452 & 452 & 243 \\
\hline & $\begin{array}{l}\text { Evapotranspiration under } \\
\text { mulching condition }(\mathrm{mm})\end{array}$ & 407 & 309 & 471 & 473 & 345 \\
\hline & Theoretical AWP $\left(10^{4} \mathrm{~m}^{3}\right)$ & 0 & 1653 & 10 & 2145 & 0 \\
\hline & Actual AWP $\left(10^{4} \mathrm{~m}^{3}\right)$ & 0 & 0 & 10 & 2145 & 0 \\
\hline \multirow{5}{*}{$75 \%$} & Evapotranspiration (mm) & 404 & 376 & 554 & 598 & 345 \\
\hline & Precipitation (mm) & 136 & 326 & 430 & 430 & 211 \\
\hline & $\begin{array}{l}\text { Evapotranspiration under } \\
\text { mulching condition (mm) }\end{array}$ & 404 & 320 & 471 & 478 & 345 \\
\hline & Theoretical AWP $\left(10^{4} \mathrm{~m}^{3}\right)$ & 0 & 1707 & 10 & 2169 & 0 \\
\hline & Actual AWP $\left(10^{4} \mathrm{~m}^{3}\right)$ & 0 & 0 & 10 & 2169 & 0 \\
\hline \multirow{5}{*}{$90 \%$} & Evapotranspiration (mm) & 407 & 383 & 554 & 609 & 345 \\
\hline & Precipitation (mm) & 149 & 199 & 340 & 340 & 172 \\
\hline & $\begin{array}{l}\text { Evapotranspiration under } \\
\text { mulching condition }(\mathrm{mm})\end{array}$ & 407 & 326 & 471 & 487 & 345 \\
\hline & Theoretical AWP $\left(10^{4} \mathrm{~m}^{3}\right)$ & 0 & 1739 & 10 & 2209 & 0 \\
\hline & Actual AWP $\left(10^{4} \mathrm{~m}^{3}\right)$ & 0 & 1739 & 10 & 2209 & 0 \\
\hline
\end{tabular}

On the premise that the yield does not decrease, the reducible irrigation water amount, which is achieved by applying covering technologies, can be regarded as the saved water amount. According to the irrigation habits in the Guanzhong region, winter 
irrigation, spring irrigation, and summer irrigation would be generally carried out in a year to meet crops' water demands in different seasons. Therefore, it is necessary to fully consider crops' water deficit and local irrigation habits when making irrigation plans for different hydrological years and calculating corresponding water-saving amount. The irrigation systems for crops in the Baojixia irrigation area for different hydrological years and savable irrigation water amount are described in Table 4.

Table 4. The AWP and irrigation schedules of Baojixia Irrigation Area in different hydrological years

\begin{tabular}{|c|c|c|c|c|c|c|c|c|}
\hline \multirow{2}{*}{$\begin{array}{l}\text { Hydrological } \\
\text { year (GRP) }\end{array}$} & \multicolumn{3}{|c|}{$\operatorname{AWP}\left(10^{4} \mathbf{m}^{3}\right)$} & \multicolumn{5}{|c|}{$\begin{array}{l}\text { Irrigation schedules (irrigation amount/ } \\
\text { irrigation times) (mm/dimensionless) }\end{array}$} \\
\hline & Total & $\begin{array}{l}\text { Resource- } \\
\text { based }\end{array}$ & $\begin{array}{l}\text { Efficiency- } \\
\text { based }\end{array}$ & $\begin{array}{l}\text { Winter } \\
\text { wheat }\end{array}$ & $\begin{array}{c}\text { Summer } \\
\text { corn }\end{array}$ & Cotton & $\begin{array}{c}\text { Fruit } \\
\text { tree }\end{array}$ & Cole \\
\hline $25 \%$ & 891 & 891 & 0 & $247 / 2$ & $0 / 0$ & $0 / 0$ & $0 / 0$ & $0 / 0$ \\
\hline $50 \%$ & 4165 & 2011 & 2154 & $195 / 2$ & $0 / 0$ & $0 / 0$ & $0 / 0$ & $0 / 0$ \\
\hline $75 \%$ & 4190 & 2011 & 2179 & $268 / 2$ & $0 / 0$ & $0 / 0$ & $0 / 0$ & $134 / 1$ \\
\hline $90 \%$ & 6883 & 2925 & 3958 & $258 / 2$ & $126 / 1$ & $147 / 1$ & $131 / 1$ & $173 / 2$ \\
\hline
\end{tabular}

\section{AWP of each irrigation area}

The Fig. 2 shows the distribution of water-saving potentials of the nine major Guanzhong irrigation areas. It can be seen from total water-saving potentials and unitarea water-saving potentials of all the irrigation areas that total water-saving potentials and unit-area water-saving potentials varied greatly among the irrigation areas. The factors influencing total water-saving potentials include area of irrigation areas, and planting proportion of main crops. It can be seen from Fig. 2 that the relatively large Baojixia irrigation area had relatively high total water-saving potential, while the relatively small Yangmaowan irrigation area and Taoqupo reservoir irrigation area had relatively low total water-saving potentials. The Jinghuiqu irrigation area, Jiaokouchouwei irrigation area, Luohuiqu irrigation area, and Shibaochuan irrigation area are close in size, but the former three irrigation areas had larger total water-saving potentials than the Shibaochuan irrigation area; that's because the planting area of summer maize and fruit trees in the former three irrigation areas was significantly higher than that in the Shibaochuan irrigation area. Fig. 3 shows the proportions of resource-based water-saving potentials and efficiency-based water-saving potentials, and it can be seen that the proportions of efficiency-based water-saving potentials of all the irrigation areas were more than $50 \%$.
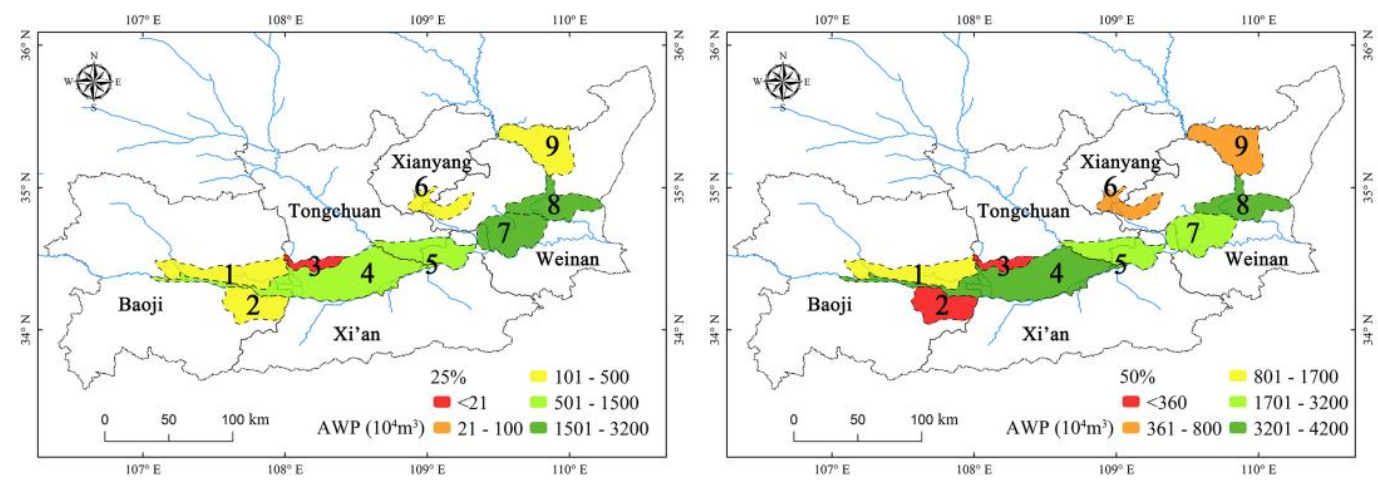

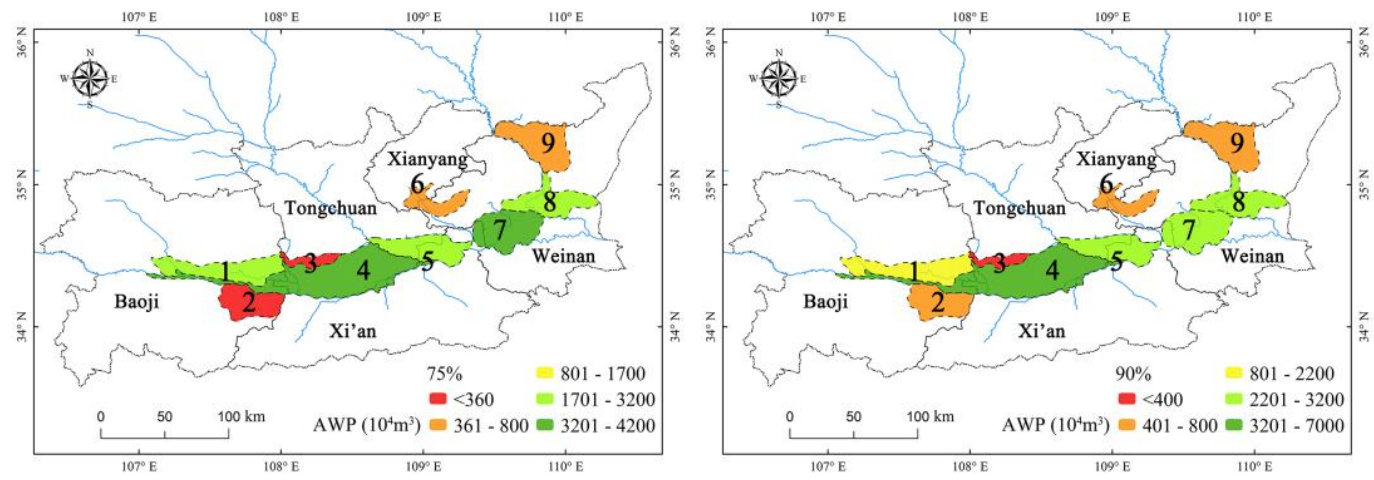

Figure 2. Map of the total AWP of each irrigations under different GRPS

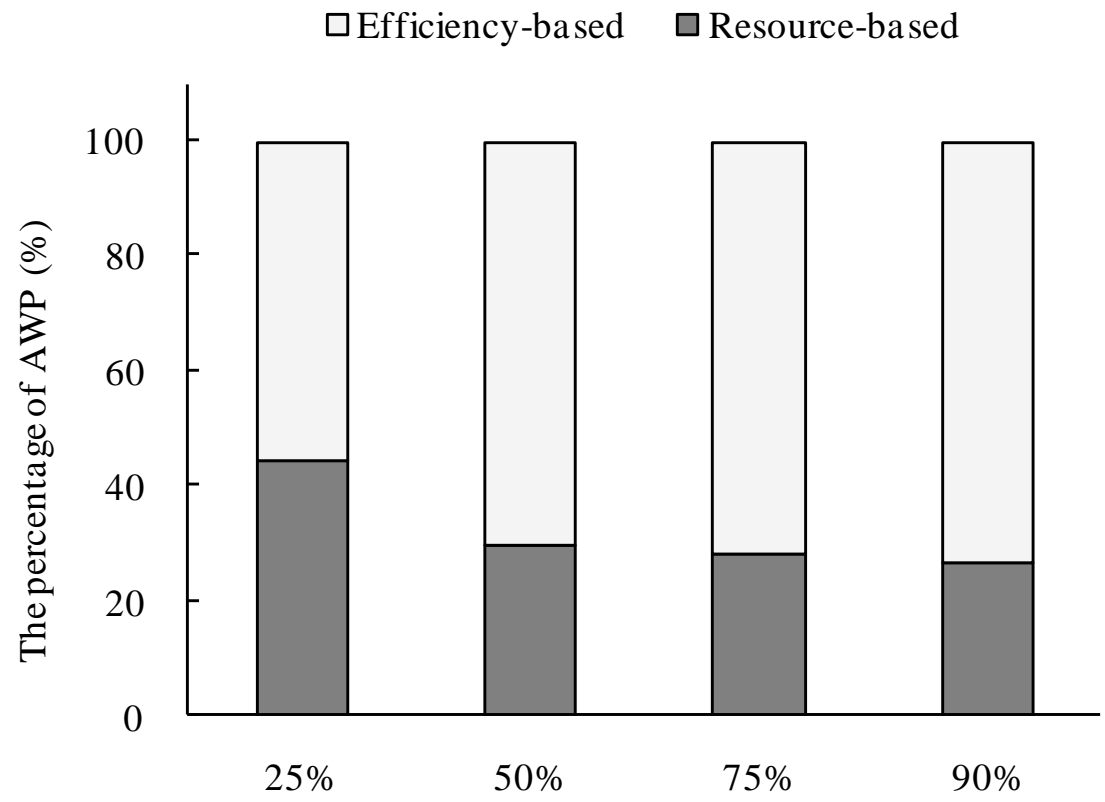

Precipitation insurance rate

Figure 3. The proportion of the resource-based (efficiency-based) AWP in Guanzhong Irrigation Area under different GRPs

\section{AWP in extreme drought condition}

In extreme weather conditions, surface evaporation and plant transpiration could be reduced by using covering technologies, and thus irrigation water would be reduced and irrigation water resources would be saved. In the Guanzhong Plain, covering technologies are generally not used in planting wheat; in the growing period of maize, wheat straw is generally used to cover the ground; wheat straw or plastic film mulching could be used in planting fruit trees; plastic film mulching is generally used in planting cotton; covering technologies are generally not used in planting rape. According to relevant data (Wang et al., 2012b), when applying covering technologies, the watersaving percentages $\left(\varphi_{2}\right)$ of summer maize, fruit trees, and cotton are respectively $15 \%$, $20 \%$, and $15 \%$. Based on the percentages, water-saving amounts of different crops were 
calculated. Water-saving potentials of main crops in Guanzhong irrigation areas under extreme drought condition are shown in Fig. 4 and Fig. 5.

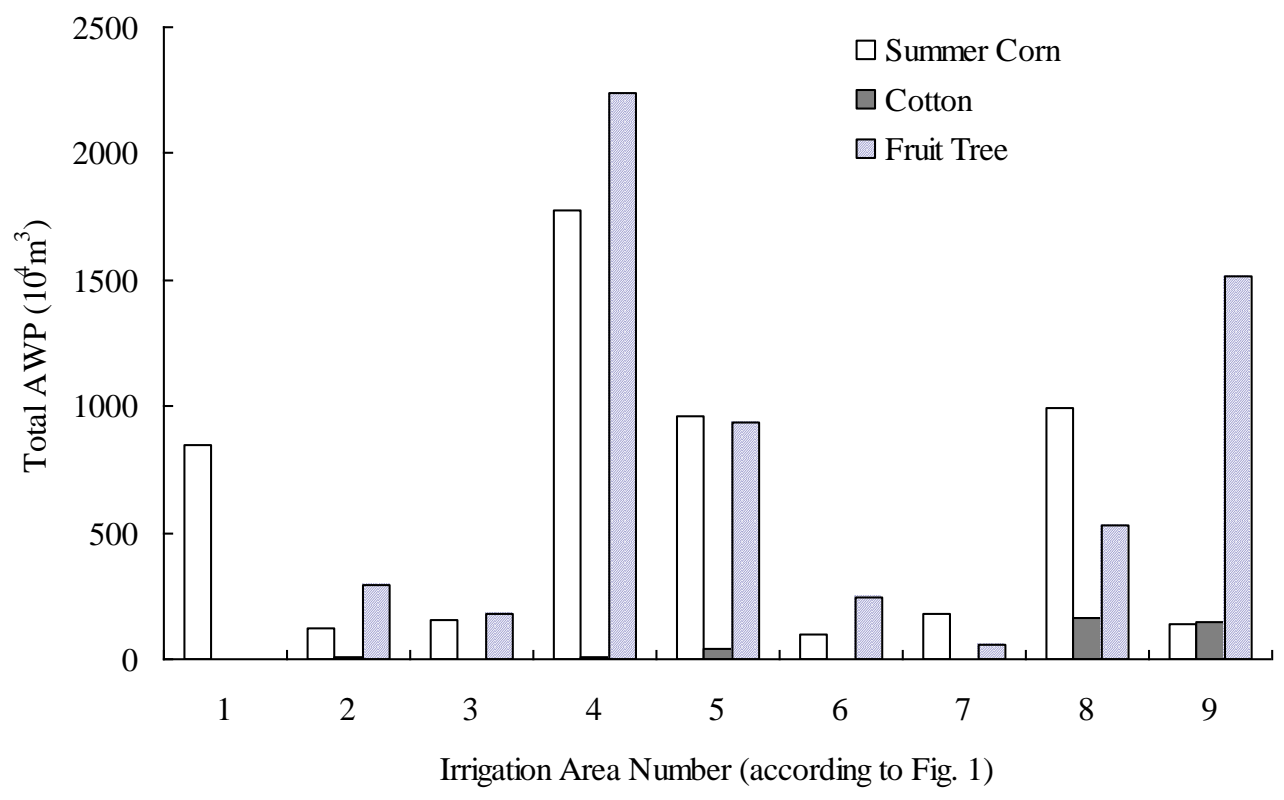

Figure 4. The total AWP of main crops in Guanzhong irrigation areas in extreme drought condition

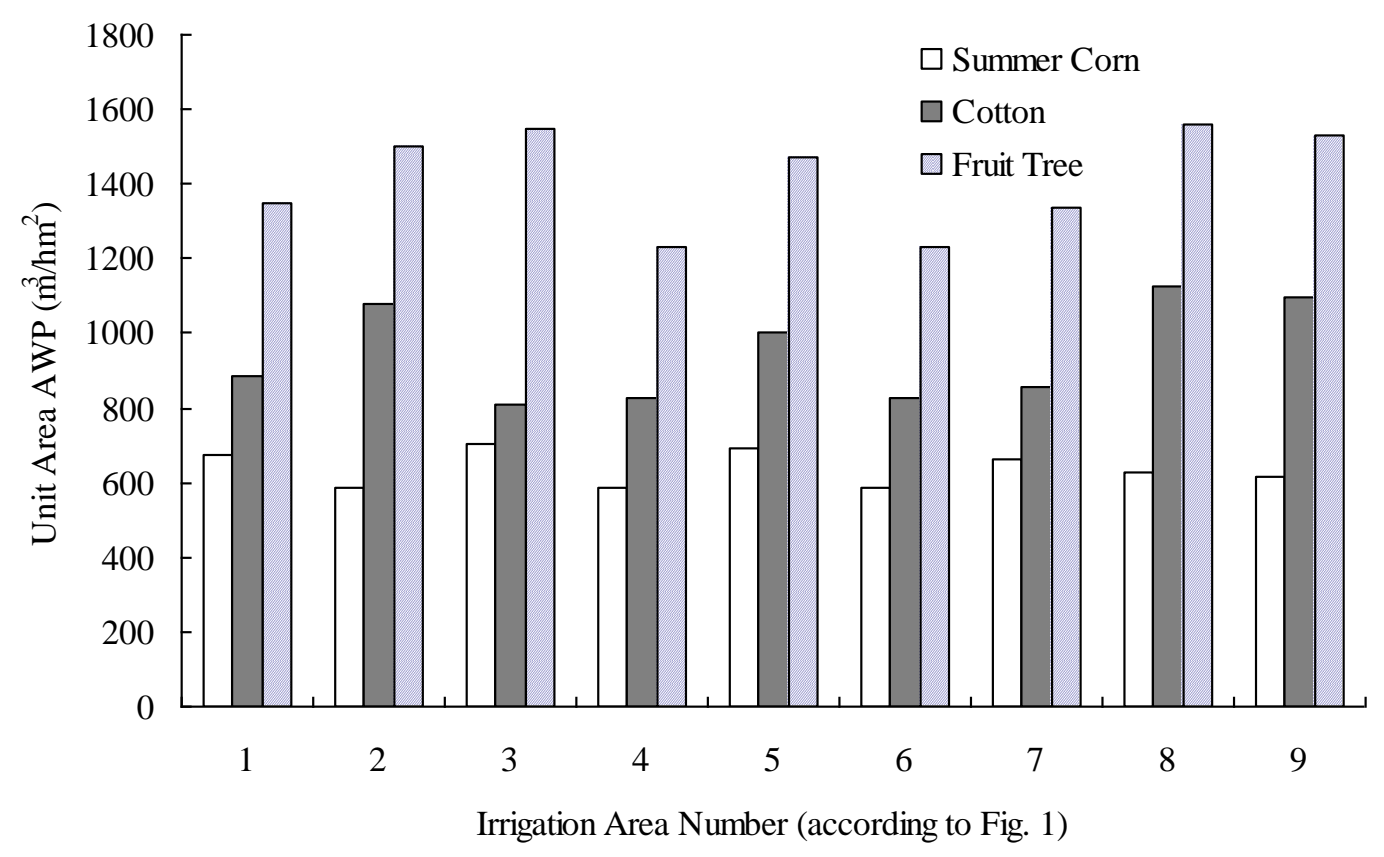

Figure 5. The unit area AWP of main crops in Guanzhong irrigation areas in extreme drought condition

From Fig. 4 and Fig. 5, it can be seen that the total water-saving potential of each irrigation area was mainly contributed by summer maize and fruit trees, which accounted for more than $95 \%$ of the total water-saving potential. By contrast, winter 
wheat and rape had very small water-saving potentials, which are not shown in the figures. In terms of unit-area water-saving amount, fruit trees, cotton, and summer maize had highest water-saving efficiency, much higher than that of rape and winter wheat. The unit-area water-saving amounts of fruit trees, cotton, and summer maize did not vary much among the nine major irrigation areas, with their average values being $9.4,6.3$, and $4.3 \mathrm{~mm}$ respectively. This result is consistent with the actual situation that the irrigation areas are located in the same climate zone and were at a similar technical level of agricultural production.

By using the main crops' water-saving potentials, the total water-saving potentials and unit-area water-saving potentials of the Guanzhong irrigation areas were obtained, as shown in Figs. 6-8.

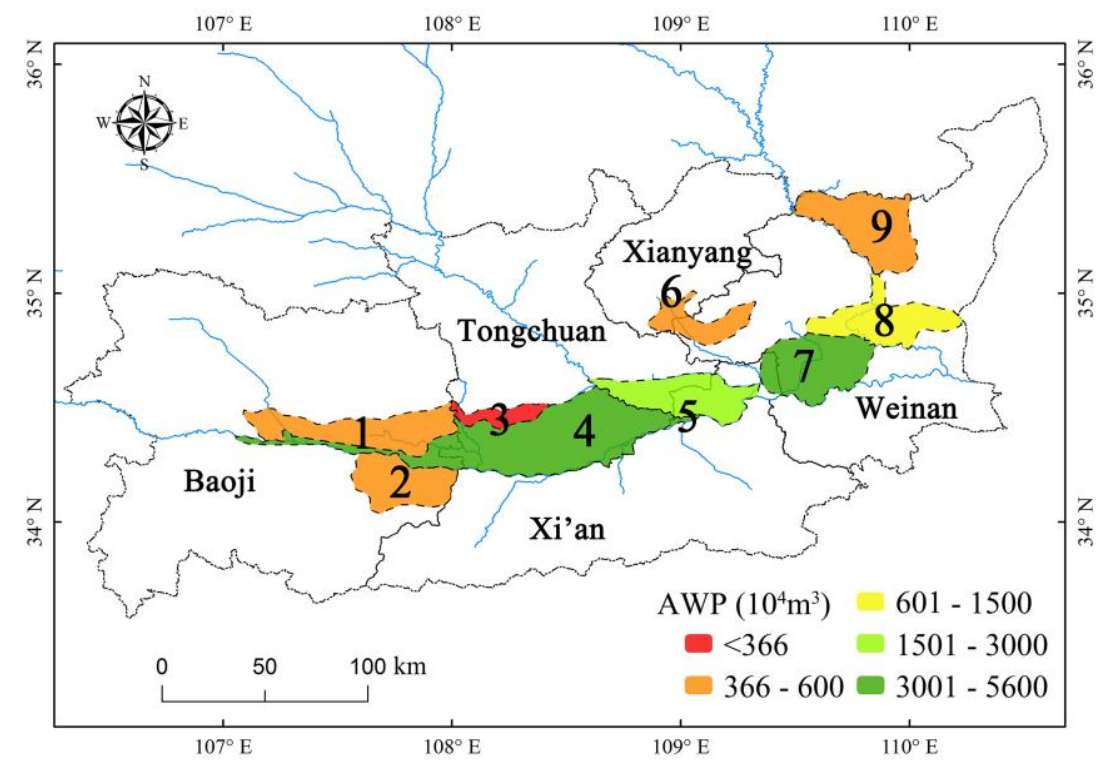

Figure 6. The total AWP in each irrigation area in extreme drought condition

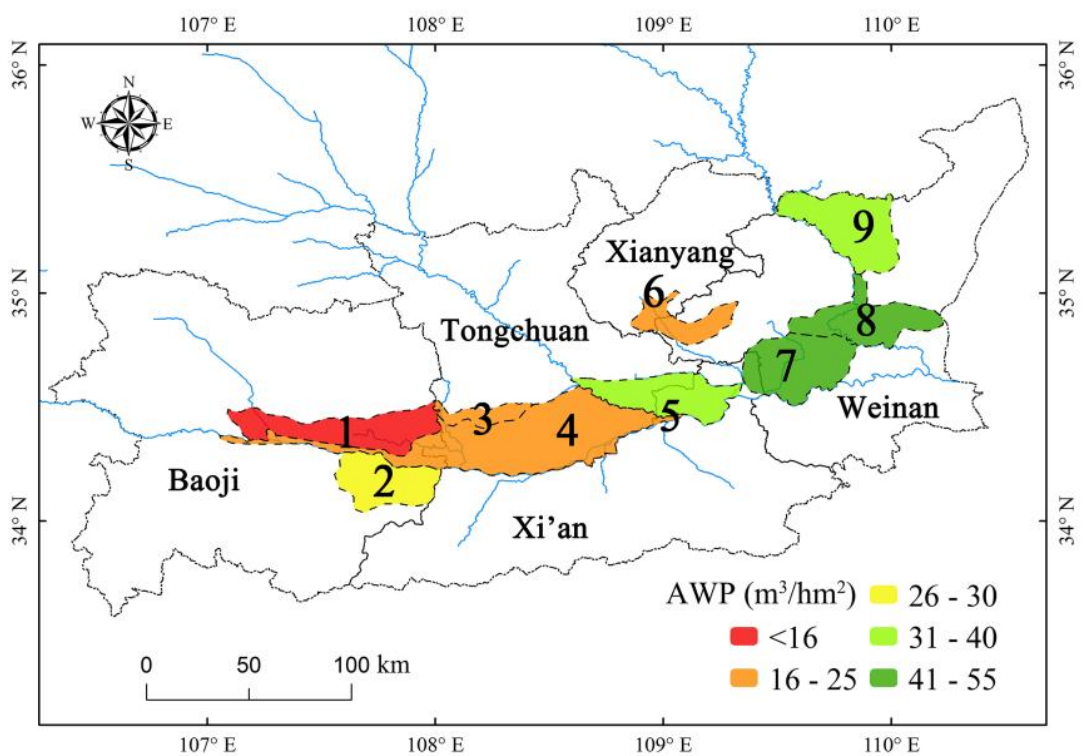

Figure 7. The unit area AWP in each irrigation area in extreme drought condition 


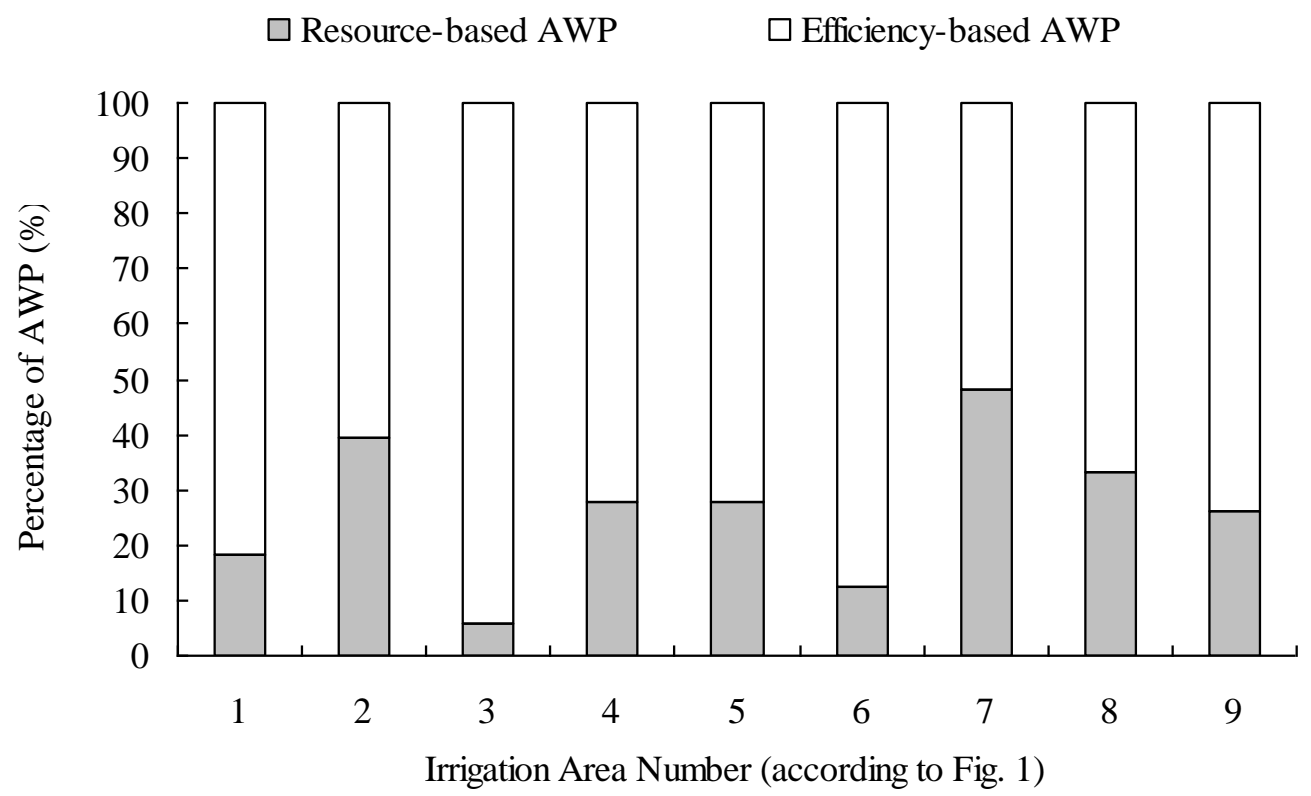

Figure 8. The percentage of the resource-based (efficiency-based) AWP in each irrigation area in extreme drought condition

It can be seen from total water-saving potentials and unit-area water-saving potentials of all the irrigation areas in extreme climate conditions that total water-saving potentials and unit-area water-saving potentials varied greatly among the irrigation areas. The factors influencing total water-saving potentials include area of irrigation areas, and planting proportion of main crops. It can be seen from Fig. 6 that the relatively large Baojixia irrigation area had relatively high total water-saving potential, while the relatively small Yangmaowan irrigation area and Taoqupo reservoir irrigation area had relatively low total water-saving potentials. The Jinghuiqu irrigation area, Jiaokouchouwei irrigation area, Luohuiqu irrigation area, and Shibaochuan irrigation area are close in size, but the former three irrigation areas had larger total water-saving potentials than the Shibaochuan irrigation area; that's because the planting area of summer maize and fruit trees in the former three irrigation areas was significantly higher than that in the Shibaochuan irrigation area.

At different hydrologic conditions (GRP of $25 \%, 50 \%, 75 \%, 90 \%$, and 95\%), the proportions of resource-based water-saving potentials and efficiency-based watersaving potentials show that the proportions of efficiency-based water-saving potentials of all the irrigation areas were more than $50 \%$. Thus it can be concluded that improvement of crops' water utilization efficiency should be in preference to improvement of water conveyance efficiency in technology innovation.

\section{Discussion and Conclusions}

Concepts and connotations of resource-based water saving and efficiency-based water saving were proposed in this study, and models for calculating water-saving potentials of the two types were established. Key parameters of the calculation models were studied in depth, and the resource-based water-saving coefficient and efficiencybased water-saving coefficient of the main crops in the typical irrigation area (Baojixia) 
were determined based on water-saving schemes for different crops. Based on the established models for calculating water-saving potentials, water-saving potentials of different crops in different water-saving schemes were calculated. In addition, possible resource-based water-saving potentials and efficiency-based water-saving potentials of the nine major irrigation areas in different hydrological years were calculated respectively.

Based on different irrigation areas' planting structure and planting scale, agricultural water-saving schemes were proposed. For the food crops-oriented Shitouhe irrigation area, it is recommended to mainly apply land leveling technology, surge flow irrigation technology or sprinkling irrigation technology, and straw mulching technology. For the commercial crops-oriented Jiaokou and Shibaochuan irrigation areas, it is recommended to apply micro-irrigation technologies and covering technologies. For the cottonoriented Luohuiqu irrigation area, it is recommended to apply land leveling technology, surge flow irrigation technology, and covering technologies, and to popularize field sprinkling irrigation and trickle irrigation technologies appropriately. For the Baojixia, Fengjiashan, Jinghuiqu, and Yangmaowan irrigation areas, which are oriented at planting food crops and commercial crops, it is recommended to apply land leveling technology, surge flow irrigation technology, and straw mulching technology according to actual circumstances, to popularize field sprinkling irrigation technology appropriately, and to vigorously popularize trickle irrigation technology in areas for planting commercial crops.

Currently, comprehensive definitions of water-saving agriculture and water-saving potential have not been given authoritatively in the research field. As a result, there are numerous directions in researches on specific issues. Thus, in researches on water utilization efficiency, it is still necessary to find out which calculation model is most practical, particularly in calculating water amount. Water-saving potentials vary greatly among research objects. Currently, researches are mainly carried out on improvements to diversion and irrigation projects and agronomic measures in the field, which actually would bring relatively static potentials. In addition, scale effect problem exists in the process of studying water utilization efficiency and water-saving potential. Regarding components of water amount, many scholars have proposed 3 scales in water balance calculation, which are respectively field scale, mesoscale, and macro-scale. As indicated by this study, resource-based water saving is more suitable for micro-scale and mesoscale, while efficiency-based water saving is more suitable for macro-scale. However, effective and reasonable methods to eliminate scale effect and realize conversion between different scales have not yet been proposed and will be an emphasis in future research.

In recent studies, AWP is generally taken as the difference between irrigation water use in a base year and that in a planned year. However, the base year is often selected at will without a standard, and the concept in this sense is not yet perfect due to the scale effect problem. Water-saving irrigation could be applied not only in irrigation agriculture, but also in dryland agriculture. However, applications in the latter are fewer than in the former, so studies on water-saving potential are mainly targeted at irrigation agriculture. In addition, studies on precipitation accumulation and utilization in the region where irrigation agriculture prevails should be enhanced.

The utilization coefficient of irrigation water is an important indicator for evaluation in water-saving agriculture, which is generally taken as the product of the utilization coefficient of channel water and the utilization coefficient of field water. Loss of 
irrigation water would directly influence the utilization efficiency of irrigation water. From this perspective, the factors influencing the utilization coefficient of irrigation water mainly include size of irrigation areas, diversion discharge, groundwater level, soil conditions, and types and technologies of anti-percolation works in irrigation areas. The following problems need to be solved in obtaining the coefficients: heavy workload; it is difficult to guarantee stable measuring conditions (that is because irrigation measurement is generally carried out in production period, during which irrigation water flow, length of channels, existence of branches, and other conditions are subject to changes, thus making measurement very difficult); a great deal of talents possessing special technical knowledge are needed in measuring the coefficients; representative evaluation of the determined coefficients is necessary. The above-mentioned problems need to be discussed in future studies.

Acknowledgements. This work was partially supported by the National Natural Science Foundation of China (NSFC) (Grant No: 41401042, 51109036, 51179032), the China Postdoctoral Science Foundation (2014M550823), the Natural Science Foundation of Heilongjiang province of China (E2015024), the Projects for Science and Technology Development of Water Conservancy Bureau in Heilongjiang Province of China $(201402,201404,201501)$, and the Academic Backbones Foundation of Northeast Agricultural University (16XG11). The authors are grateful to the reviewers for the help and thoughtprovoking comments.

\section{REFERENCES}

[1] Belder, P., Bouman, B. A. M., Cabangon, R., Lu, G., Quilang, E. J. P., Li, Y., Spiertz J. H. J., Tuong, T. P. (2004): Effect of water-saving irrigation on rice yield and water use in typical lowland conditions in Asia. - Agricultural Water Management 65(3): 193-210.

[2] Bennett, D. R., Harms, T. E., Entz, T. (2014): Net irrigation water requirements for major irrigated crops with variation in evaporative demand and precipitation in southern alberta. - Canadian Water Resources Journal 39(1): 63-72.

[3] Bobée, B. (1975): The log pearson type 3 distribution and its application in hydrology. Water Resources Research 11(5): 681-689.

[4] Chen, F, Cai, H., Wang, J. (2004): Evaluation of crop water requirement and crop coefficient of straw-mulched summer maize. - Journal of Irrigation and Drainage 23(1): 41-43.

[5] Damerau, K., Patt, A. G., Vliet, O. P. R. V. (2016): Water saving potentials and possible trade-offs for future food and energy supply. - Global Environmental Change 39: 15-25.

[6] Dixon, A., Butler, D., Fewkes, A. (1999): Water saving potential of domestic water reuse systems using greywater and rainwater in combination. - Water Science and Technology 39(5): 25-32.

[7] Fan, J., Tian, F., Yang, Y. H., Han, S. M., Qiu, G. Y. (2010): Quantifying the magnitude of the impact of climate change and human activity on runoff decline in mian river basin, china. - Water Science and Technology 62(4): 783-91.

[8] Feng, J., Yan, D., Li, C., Gao, Y., Liu, J. (2014): Regional frequency analysis of extreme precipitation after drought events in the heihe river basin, northwest china. - Journal of Hydrologic Engineering 19(6): 1101-1112.

[9] Horst, M. G., Shamutalov, S. S., Pereira, L.S., Gonçalves, J. M. (2005): Field assessment of the water saving potential with furrow irrigation in fergana, aral sea basin. Agricultural Water Management 77(1-3): 210-231. 
[10] Hu, Y., Moiwo, J. P., Yang, Y., Han, S., Yang, Y. (2010): Agricultural water-saving and sustainable groundwater management in Shijiazhuang irrigation district, north china plain. - Journal of Hydrology 393(3-4): 219-232.

[11] Huffaker, R., Whittlesey, N. (2003): A theoretical analysis of economic incentive policies encouraging agricultural water conservation. - International Journal of Water Resources Development 19(1): 37-53.

[12] Karimov, A., Molden, D., Khamzina, T., Platonov, A., Ivanov, Y. (2012): A water accounting procedure to determine the water savings potential of the fergana valley. Agricultural Water Management 108(2): 61-72.

[13] Kifle, M., Gebretsadikan, T. G. (2016): Yield and water use efficiency of furrow irrigated potato under regulated deficit irrigation, atsibi-wemberta, north ethiopia. - Agricultural Water Management 170: 133-139.

[14] Li, Y., Liu, H., Huang, G. (2012): Effects of different tillage methods on soil water content and water productivity of silage summer maize. - Transactions of the Chinese Society of Agricultural Engineering 28(14): 91-98.

[15] Liu, H., Yang, H., Wang, H., Wang, Y. (2013): Real water-saving modes in Guanzhong irrigation area of Shaanxi province. - Journal of Beijing Normal University (Natural Science) 49(2-3): 210-213.

[16] Ministry of Housing and Urban-Rural Development of the P. R. China. (2006): Technical specification for water-saving irrigation engineering, GB/T 50363-2006. Beijing: Ministry of Housing and Urban-Rural Development of the P. R. China.

[17] Ministry of Water resources of the P. R. China. (2015): China water resources bulletin 2015. Beijing: Ministry of Water resources of the P. R. China.

[18] Moiwo, J. P., Yang, Y. H., Li, H. L., Han, S. M., Hu, Y. K. (2009): Comparison of grace with in situ hydrological measurement data shows storage depletion in hai river basin, northern china. - Water SA 35(5): 663-670.

[19] Nair, S., Johnson, J., Wang, C. (2013): Efficiency of irrigation water use: a review from the perspectives of multiple disciplines. - Agronomy Journal 105(2): 351-363.

[20] Pereira, L. S., Allen, R. G., Smith, M., Raes, D. (2015): Crop evapotranspiration estimation with FAO56: Past and future. - Agricultural Water Management 147: 4-20.

[21] Pereira, S. L. (2017): Water, agriculture and food: Challenges and issues. - Water Resources Management 31(10): 2985-2999.

[22] Siderius, C., Boonstra, H., Munaswamy, V., Ramana, C., Kabat, P., Ierland, E. V., Hellegers, P. (2015): Climate-smart tank irrigation: a multi-year analysis of improved conjunctive water use under high rainfall variability. - Agricultural Water Management 148(1): 52-62.

[23] Standardization Administration of the P. R. China. (2006): Technical specification for irrigation projects with low pressure pipe conveyance, GB/T 20203-2006. Beijing: Standardization Administration of the P. R. China.

[24] Tang, J., Folmer, H., Vlist, A. J. V. D., Xue, J. (2014a): The impacts of management reform on irrigation water use efficiency in the guanzhong plain, china. - Papers in Regional Science 93(2): 455-475.

[25] Tang, J., Folmer, H., Xue, J. (2014b): Technical and allocative efficiency of irrigation water use in the Guanzhong plain, china. - Food Policy 50: 43-52.

[26] Tang, J., Folmer, H., Xue, J. (2016): Adoption of farm-based irrigation water-saving techniques in the guanzhong plain, china. - Agricultural Economics 47(4): 445-455.

[27] Wang, H., Li, L., Wang, H., Zhai Y. (2011): Study on agricultural water-saving potential in Guanzhong region. - International Symposium on Water Resource and Environmental Protection 2: 1111-1115. IEEE.

[28] Wang, P., Song, X., Han, D., Zhang, Y., Zhang, B. (2012a): Determination of evaporation, transpiration and deep percolation of summer corn and winter wheat after irrigation. - Agricultural Water Management 105(1): 32-37. 
[29] Wang, Y., Wang, H., Liu, H., Gao, J. (2012b): Agricultural water saving potential in Guanzhong irrigation districts under extreme climate conditions. - Journal of Beijing Normal University (Natural Science) 48(5): 577-581.

[30] Wu, B., Yan, N., Xiong, J., Bastiaanssen, W. G. M., Zhu, W., Stein, A. (2012): Validation of ETwatch using field measurements at diverse landscapes: a case study in hai basin of china. - Journal of Hydrology 436-437(5): 67-80.

[31] Wu, H., Qian, H., Chen, J., Huo, C. (2017): Assessment of Agricultural Drought Vulnerability in the Guanzhong Plain, China. - Water Resources Management 31: 15571574.

[32] Wu, J., Sun, Z. (2016): Evaluation of shallow groundwater contamination and associated human health risk in an alluvial plain impacted by agricultural and industrial activities, mid-West China. - Expo Health 8(3): 311-329.

[33] Yan, N., Wu, B., Perry, C., Zeng, H. (2015): Assessing potential water savings in agriculture on the hai basin plain, china. - Agricultural Water Management 154: 11-19.

[34] Yang, H., Zhou, Y., Liu, J. (2009): Land and water requirements of biofuel and implications for food supply and the environment in China. - Energy Policy 37(5): 18761885.

[35] Yang, Y., Hu, Y., Zhang, X. (2012): Agricultural water-saving: recent progress and future challenges. - Bulletin of the Chinese Academy of Sciences 27(4): 455-461.

[36] Yang, Y., Tian, F. (2009): Abrupt change of runoff and its major driving factors in haihe river catchment, china. - Journal of Hydrology 374(3-4): 373-383.

[37] Yin, J., Wang, H., Cai, Y. (2016): Water footprint calculation on the basis of input-output analysis and a biproportional algorithm: a case study for the yellow river basin, china. Water 8(9): 363.

[38] Yin, J., Wang, H., Liu, H., Wang, Y. (2013): Agricultural water saving potential for typical crops in Guanzhong area. -Journal of Beijing Normal University (Natural Science) 49(2/3): 205-209.

[39] Yurdusev, M.A., Kumanlığlu, A.A. (2008): Survey-based estimation of domestic water saving potential in the case of manisa city. - Water Resources Management 22(3): 291305 .

[40] Zhang, D., Guo, P. (2016): Integrated agriculture water management optimization model for water saving potential analysis. - Agricultural Water Management 170: 5-19.

[41] Zhang, Q., Yang, X., Xue, C., Yan, W., Yang, J, Zhang, T., Bauman, B. A. M., Wang, H. (2007): Analysis of coupling degree between crop water requirement of aerobic rice and rainfall in beijing areas. -Transactions of the Chinese Society of Agricultural Engineering 23(10): 51-56.

[42] Zhang, Y., Shen, Y., Xu, X., Sun, H., Li, F., Wang, Q. (2013): Characteristics of the water-energy-carbon fluxes of irrigated pear (pyrus bretschneideri rehd) orchards in the north china plain. - Agricultural Water Management 128(13): 140-148.

[43] Zuo, Y., Pang, H., Li, Y., Tian, C., Tang, J. (2010): Effects of plastic mulching on ETc, $\mathrm{Kc}$ and WUE of cotton in northern Shandong Province. - Chinese Journal of Agrometeorology 31(1): 37-40. 